\section{Scientists bemoan lack of finances for new center}

March 26th saw the official opening of the AUS\$10 million (US\$ 6.3 million), federally funded, Australian Genome Research Facility (AGRF), which has divisions in Melbourne and Brisbane. The AGRF offers antipodean researchers facilities for highthroughput gene sequencing and genotyping services, and perhaps more importantly, embodies hopes for an Australian stake in the genomerevolution.

The facility represents the most notable commitment by the federal government to genome research to-date. But far from rejoicing, scientists are questioning the government's genuine commitment to this field of research, because although the AGRF has broken even financially after a year of contract work, it has no operating budget with which to recruit staff or participate in major international projects.

AGRF director John Mattick explains, "we need core funding so we're not just lurching along on customer charges." Mattick, who has asked the federal government for an annual AUS\$2 million, warns that the facility's potential will not be reached without substantial funds for basic genome research projects. He wants the country's federal funding agency for biomedical research, the National Health and Medical Research Council, to dedicate AUS $\$ 20$ million annually to projects such as the mouse and zebrafish genome sequencing project, high density mutation screening, and pathogen sequencing.

Australia's Health Minister, Michael Wooldridge, to whom the Prime Minister recently gave special responsibility for biotechnology, praises the foresight of the AGRF's founders for establishing a "valuable resource" that will "enable Australian researchers and companies to play a major role in the biotechnology revolution." And he defends the government's contribution of a AUS $\$ 10$ million establishment grant as adequate. "The sponsors of the facility are expected to manage its operation from within their own resources," Wooldridge told Nature M edicine. "The re searchers associated with the facility are highly regarded within the Australian and international research sceneand I am confident of their ability to attract significant research funds from [other sources] to support the facility," says Wool ridge.

The Melbourne division of AGRF, Iocated within the Walter and Eliza Hall Institute of M edical Research (WEHI), has responsibility for genotyping and muta-

tion detection, while the Brisbane division handles DNA sequencing for more than further in order to be able to release the facility's full potential." respond to the Wills report on medical re500 medical and agricultural research groups. WEHI director Suzanne Cory sees AGRF as "a catalyst that's going to make the power of modern genetics accessible right across the spectrum of research in Australia;" but adds, "we need to invest

This year is pivotal for the country's $R \& D$ future, with the government set to search this month, and a review of the capital gains tax intended to offset invest-

\title{
Stem cell debate heats up as guidelines are prepared
}

The argument over whether US government funding can be used for human embryonic stem cell research has intensified, on paper at least, and looks likely to enter its most critical period in the next three months.

Although the Department of Health and Human Services (HHS) gave the green light to federal funding for such research in January, 70 members of Congress have since contested the agency's legal reasoning in a letter to HHS Secretary Donna Shalala. And last month, 33 Nobel laureates wrote to Congress urging federal funding for human stem cell research.

All eyesare now on guidelines for this research being drawn up by the National Bioethics Advisory Commission (NBAC) at the request of Harold Varmus, director of the National Institutes of Health (NIH). Once the guidelines have been established, the NIH will begin accepting and reviewing grant applications for such studies.

The issue central to the legal debate is the distinction between the derivation and use of the cells. In their letter of objection, the Congressmen, most of whom are Republicans, assert that "any NIH action to initiate funding of such research would violate both the letter and spirit of the federal law." They are referring to wording in the 1996 appropriations bill, which includes a rider prohibiting "research in which a human embryo or embryos are destroyed, discarded, or knowingly subjected to risk of injury or death..." Congressional aides say that new legislation banning stem cell research has not been ruled out by the letter's signatories.

Proponents of stem cell research counter that since the cells have al ready been isolated and cultured as immortal lines, sub- ment in biotechnology later in the year. "It's absolutely essential that the public and industry sectors grow side by side...after all this is the strength of American science," says Cory.

According to geneticist Bob Williamson, director of the Murdoch Institute, Australia's lack of competitiveness in genomics has revolved around an overall weakness in human molecular genetics due to a lack of biotechnology start-up companies. The implementation of the Wills report-which calls for a doubling of funding for medical research (Nature Med. 59; 1999)—will be "as critical as the AGRF itself," he says.

RADA ROUSE, Brisbane

sequent work on them would not entail destroying embryos, so this research could befunded by the NIH.

John Fletcher, University of Virginia, a member of NBAC, insists that the possible medical benefits of stem cell research make a legislative ban unlikely. "There are certainly more votes [in favor of funding] because of advances in research," says Fletcher, adding that he believes the appropriations committee is leaning towards lifting the current restrictions on embryo research rather than strengthening them.

The letter from the Nobel laureates, written under the aegis of the American Society for Cell Biology, points to the "serious negative consequences" of not funding federal research programs: "The net effect will be to bar the majority of the Nation's most prominent researchers who are supported by the National Institutes of Health and the National Science Foundation at universities and non-profit institutions throughout the country [those most qualified to make dramatic advances towards using stem cells for the treatment of disease] from engaging in this critical research." Theletter goes on to say that "any new scientific understanding that emerges would not flow into the public domain and may be restricted to the commercial sector."

At NBACs meeting last month, preliminary discussion seemed to be leaning towards permitting both the use and derivation of human stem cells in federally funded studies, according to NBAC's executive director, Eric Meslin. NBAC's recommendations for research guidelines will be released in June.

Karen Birmingham \& Alan Dove, NEW YoRK 